\title{
PEMBERIAN MOTIVASI DAN INTENSIF TERHADAP KINERJA PEGAWAI BADAN PENGELOLA PAJAK DAN RETRIBUSI KOTA BANDAR LAMPUNG
}

\author{
Trisnowati Josiah $^{(1)}$, Rafian Joni ${ }^{(2)}$ \\ Universitas Sang Bumi Ruwa Jurai \\ trisnowatij@gmail.com,rafianjoni4@gmail.com
}

\begin{abstract}
Abstrak. Tujuan dari penelitian ini ingin mengetahui pengaruh motivasi terhadap kinerja pegawai Badan Pengelola Pajak dan Retribusi Daerah Kota Bandar Lampung dan ingin mengetahui pengaruh insentif terhadap kinerja pegawai serta ingin melihat pengaruh motivasi dan insentif secara bersama-sama terhadap kinerja pegawai Badan Pengelola Pajak dan Retribusi Daerah Kota Bandar Lampung.Teknik pengambilan data dilakukan melalui penyebaran angket/kuisioner kepada 75 responden, kemudian dilakukan tabulasi data dan analisa data untuk menjawab hipotesis dengan bantuan program SPSS versi 21. Hasil penelitian menunjukkan ada pengaruh motivasi terhadap kinerja pegawai, hal ini terbukti dari Uji Hipotesis Parsial melalui uji t (tes) sebesar $13,80 \%$, sedangkan insentif ada pengaruh terhadap kinerja pegawai sebesar $2,60 \%$, selanjutnya ada pengaruh motivasi dan insentif secara bersama-sama terhadap kinerja pegawai dibuktikan dengan hasil perhitungan uji Ftabel sebesar 16,30\%.Diketahui bahwa pengaruh motivasi (X1) lebih dominan daripada variabel insentif (X2) terhadap kinjerja pegawai Badan Pengelola dan Retribusi Daerah Kota Bandar Lampung. Kata kunci: Motivasi, Insentif dan Kinerja Pegawai
\end{abstract}

\section{PROVISION OF MOTIVATION AND INTENSIVE ON THE PERFORMANCE AN EMPLOYEES OF TAX MANAGEMENT AGENCY AND RETRIBUTION IN BANDAR LAMPUNG CITY}

\author{
Trisnowati Josiah ${ }^{(1)}$, Rafian Joni( ${ }^{(2)}$ \\ Sang Bumi Ruwa Jurai UniversitY \\ trisnowatij@gmail.com,rafianjoni4@gmail.com
}

\begin{abstract}
The purpose of this study was to determine the effect of motivation on the performance of employees of the Regional Tax and Levy Management Agency of Bandar Lampung City and wanted to know the effect of incentives on employee performance and to see the effect of motivation and incentives together on the performance of the Regional Tax and Levy Management Agency of Bandar Lampung. Lampung. Data collection techniques were carried out by distributing questionnaires/questionnaires to 75 respondents, then data tabulation and data analysis were carried out to answer hypotheses with the help of the SPSS version 21 program. The results showed that there was an influence of motivation on employee performance, this was evident from the Partial Hypothesis Testing through t test (test) of 13.80\%, while incentives have an effect on employee performance of $2.60 \%$, then there is an effect of motivation and incentives together on employee performance as evidenced by the results of the Ftable test calculation of $16.30 \%$. that the influence of motivation (X1) l more dominant than the incentive variable (X2) on the performance of employees of the Regional Management and Retribution Agency of Bandar Lampung City.
\end{abstract}

Keywords: Employee Motivation, Incentives and Performance. 


\section{PENDAHULUAN}

Seiring meningkatnya efek teknologi dan telekomunikasi yang telah berhasil "mengecilkan" ukuran dunia, pergerakan keragaman para pekerja (profesional) membawa nilai-nilai, perspektif dan ekspektasi yang berbeda diantara mereka (para pekerja). Kesadaran publik semakin lama semakin sensitif dan menuntut organisasi agar semakin profesional dan bertanggung jawab secara sosial seperti halnya negara-negara dunia ketiga. Kita pun telah turut terlibat dalam persaingan pasar global dan melebarkan arena bagi aktivitas penjualan dan pelayanan.

Sebagai hasil kekuatan perubahan diatas, organisasi didesak untuk mengadopsi "paradigma baru" atau melihat dunia saat ini secara lebih sensitif, fleksibel dan mudah menyesuaikan diri dengan tuntutan dan harapan para stakeholders. Saat ini para pimpinan / manajer harus bekerja dengan pengambilan keputusan yang vital yang tidak dapat mengacu pada arah-arah pengembangan dimasa yang lalu.

Teknik-teknik manajemen harus secara berkesinambungan memperhatikan perubahan dilingkungan dan organisasinya, mengukur perubahan dan mengelolanya. Untuk itu diperlukan mindset yang baru, baik dalam pemahaman maupun pengelolaan organisasi dan manusia yang ada didalamnya.

Berkaitan dengan fenomena tersebut, sektor publik dalam hal ini pemerintah khususnya Pemerintah Kota Bandar Lampung, dituntut pula untuk menciptakan sistem administrasi negara (aparatur pemerintahan) yang mumpuni dan mampu bersinergi antar lembaga. Penciptaan aparatur pemerintahan merupakan bagian yang tidak terpisahkan dari proses menciptakan kehidupan berbangsa dan bernegara yang demokratis serta menjunjung tinggi hukum dalam arti yang sebenarnya. Administrasi negara dapat diartikan sebagai apa yang dilakukan pemerintah atau oleh instansi, mulai dari perencanaan hingga tahap evaluasi, demikian seterusnya. Kegiatan administrasi negara ini juga termasuk kegiatan menyerap aspirasi masyarakat, mengolah data/informasi dan menyampaikan kepada policy makers, serta mengawasi, mengendalikan dan mengevaluasi pelaksana kebijakan publik.

Besarnya perhatian masyarakat terhadap kinerja aparatur pemerintah dewasa ini, maka dibutuhkan adanya peningkatan kinerja yang optimal dan mampu mendayagunakan potensi sumber daya manusia yang dimiliki oleh pegawai guna menciptakan tujuan organisasi, diperlukan adanya peran organisasi dalam meningkatkan kinerja yang efektif dan efisien.

Upaya menciptakan kinerja yang tinggi, organisasi perlu memperhatikan berbagai faktor yang dapat mempengaruhi kinerja pegawai. Motivasi mempunyai peranan yang sangat besar dan berpengaruh terhadap tingkat efektivitas pekerjaan pegawai karena tanpa adanya motivasi kerja pegawai niscaya pekerjaan tersebut tidak akan terlaksana dengan baik dan lancar. Motivasi dapat dijadikan sebagai landasan proses pembentukan, pemberdayaan dan pengembangan sumber daya manusia. Untuk tercapainya tujuan organisasi, menurut (Stevy Moniharapon 2018) pegawai memerlukan motivasi untuk bekerja lebih rajin, pegawai diperlukan perhatian lebih serius terhadap tugas yang dikerjakan sehingga tujuan organisasi tercapai. Dengan motivasi kerja yang tinggi, pegawai akan bekerja lebih giat didalam melaksanakan pekerjaannya, sebaliknya 
Vol 6, No 2, 2020

dengan motivasi yang rendah tidak mempunyai semangat kerja mudah menyerah dalam menyelesaikan pekerjaannya.

Untuk dapat mengikuti perkembangan yang ada dan tercapainya tujuan organisasi, pegawai mampu bekerja dengan baik, salah satunya diberi insentif sebagai perangsang untuk memacu agar bekerja lebih baik lagi agar pendapatan daerah dapat memenuhi target bahkan melampaui target yang telah ditetapkan dalam Anggaran Pendapatan Daerah Kota Bandar Lampung. Namun kenyataannya insentif tersebut tidak rutin diberikan kepada pegawai setiap bulan, walaupun pegawai telah bekerja dan berusaha untuk memenuhi target bahkan melampaui target yang telah ditetapkan oleh Pemerintah Kota Bandar Lampung.

Berdasarkan pengamatan penulis bahwa motivasi masih rendah, kurangnya perhatian atasan terhadap pegawai dalam melaksanakan tugas begitu juga pemberian insentif masih sangat rendah dimana dibuktikan seringnya insentif tidak diberikan secara rutin setiap bulan terhadap petugas pemungut Pendapatan Daerah Kota Bandar Lampung yang berdampak terhadap kinerja pegawai rendah pada Badan Pengelola Pajak dan Retribusi Daerah Kota Bandar Lampung.

Rekapitulasi Daftar Hadir Pegawai Badan Pengelola Pajak dan Retribusi Daerah Kota Bandar Lampung

\begin{tabular}{clcccccc}
\hline & & \multirow{2}{*}{ Numlah } & \multicolumn{5}{c}{ Tahun 2020} \\
Keterangan \\
& Bulan & Pegawai & Sakit & Izin & Alfa & Jumlah & $\%$ \\
\hline 1 & Januari & 75 & 4 & 3 & 2 & 9 & 12 \\
2 & Februari & 75 & 2 & 4 & 2 & 8 & 10,7 \\
3 & Maret & 75 & 3 & 2 & 3 & 8 & 10,7 \\
4 & April & 75 & 3 & 5 & 2 & 10 & 13,3 \\
5 & Mei & 75 & 2 & 3 & 3 & 8 & 10,7 \\
6 & Juni & 75 & 3 & 4 & 2 & 9 & 12 \\
7 & Juli & 75 & 2 & 3 & 2 & 7 & 9,3 \\
8 & Agustus & 75 & 3 & 2 & 1 & 6 & 8 \\
9 & September & 75 & 2 & 3 & 2 & 7 & 9,3 \\
10 & Oktober & 75 & 1 & 4 & 3 & 8 & 10,7 \\
11 & November & 75 & 2 & 1 & 2 & 5 & 6,7 \\
12 & Desember & 75 & 2 & 3 & 1 & 6 & 8 \\
& & & & & & &
\end{tabular}

Sumber : Sub Bagian Kepegawaian Badan Pengelola Pajak dan Retribusi Daerah Kota Bandar Lampung

Daftar Insentif Pegawai Tahun 2020

\begin{tabular}{ccccccc}
\hline No & $\begin{array}{c}\text { Jumlah } \\
\text { Pegawai }\end{array}$ & $\begin{array}{c}\text { Insentif } \\
\text { untuk 1 } \\
\text { triwulan }\end{array}$ & $\begin{array}{c}\text { Jumlah } \\
\text { insentif yang } \\
\text { harus diterima } \\
\text { setiap 1 } \\
\text { triwulan }\end{array}$ & $\begin{array}{c}\text { Jumlah } \\
\text { insentif } \\
\text { yang } \\
\text { dibayar }\end{array}$ & $\begin{array}{c}\text { Kekurangan } \\
\text { yang belum } \\
\text { dibayar }\end{array}$ & Ket \\
\hline 1 & 75 & 3.000 .000 & 225.000 .000 & 150.000 .000 & 75.000 .000 & Tw 1 \\
2 & 75 & 3.000 .000 & 225.000 .000 & 150.000 .000 & 75.000 .000 & Tw 2 \\
3 & 75 & 3.000 .000 & 225.000 .000 & 150.000 .000 & 75.000 .000 & Tw 3 \\
4 & 75 & 3.000 .000 & 225.000 .000 & 150.000 .000 & 75.000 .000 & Tw 4
\end{tabular}

Sumber : Sub Bagian Kepegawaian Badan Pengelola Pajak dan Retribusi Daerah Kota Bandar Lampung

Berdasarkan uraian tersebut diatas, maka penulis tertarik untuk mengadakan penelitian dengan judul Pengaruh Motivasi dan Insentif terhadap Kinerja Pegawai pada Badan Pengelola Pajak dan Retribusi Daerah Kota Bandar Lampung.

\section{TINJAUAN TEORITIS}

\section{Motivasi}

Menurut (Suranto 2013), motivasi adalah suatu faktor yang mendorong seseorang untuk melakukan suatu perbuatan atau kegiatan tertentu. Oleh karena itu motivasi sering kali diartikan pula sebagai faktor pendorong perilaku seseorang setiap tindakan yang dilakukan oleh seorang manusia pasti memiliki sesuatu faktor yang mendorong perbuatan tersebut. Motivasi atau dorongan untuk bekerja ini sangat penting bagi tinggi rendahnya produktivitas perusahaan. Tanpa adanya motivasi dari para karyawan atau pekerja untuk bekerja sama bagi kepentingan perusahaan maka tujuan yang telah diterapkan tidak akan tercapai, sebaliknya apabila terdapat motivasi yang besar dari para karyawan maka hal tersebut merupakan suatu jaminan atas keberhasilan perusahaan dalam mencapai tujuannya, motivasi merupakan kegiatan yang mengakibatkan menyalurkan dan memelihara perilaku manusia. Motivasi ini merupakan subjek yang penting bagi manajer, karena manajer harus bekerja 
dengan dan melalui orang lain. Pemimpin perlu memahami orang-orang yang berperilaku tertentu agar dapat mempengaruhi untuk bekerja sesuai dengan yang diinginkan organisasi (Robbin 2008)

\section{Macam-Macam Motivasi}

Menurut (Suranto 2013) ada tiga tipe kebutuhan Motivasi, yaitu:

1. Need for Power, yaitu manusia yang mempunyai keinginan berkuasa tinggi mempunyai keinginan yang besar untuk menanamkan pengaruhnya dan mengendalikan orang lain,

2. Need for Affiliation, yaitu manusia mempunyai kebutuhan afiliasi yang tinggi, umumnya senang sosialisasi, senang dicintai dan tidak menyukai kesendirian, dan terakhir

3. Need for Achievement, yaitu manusia mempunyai kebutuhan berprestasi tinggi, mempunyai keinginan tinggi untuk sukses.

Motivasi atau dorongan kepada karyawan untuk bersedia bekerja sama demi tercapainya tujuan bersama ini terdapat dua macam, yaitu :

1. Motivasi finansial, yaitu dorongan yang dilakukan dengan memberikan imbalan finansial kepada karyawan. Imbalan tersebut bersifat motivasi

2. Motivasi non finansial, yaitu dorongan yang diwujudkan tidak dalam bentuk finansial uang, akan tetapi berupa hal-hal seperti pujian, penghargaan, pendekatan manusia dan lain sebagainya.

Menurut (Aprianis 2019), mendefinisikan bahwa "Insentif merupakan imbalan langsung yang dibayarkan kepada pegawai karena kinerjanya melebihi standar yang ditentukan."

Senada dengan pendapat diatas yang mengartikan insentif sebagai imbalan atas kinerja yang melebihi standar (Pratama and Sunuharyo n.d.), mendefinisikan sebagai berikut: Pemberian insentif merupakan daya perangsang yang kuat untuk meningkatkan semangat dan gairah kerja. Akan tetapi tindakan ini perlu dijaga supaya dalam melaksanakan pekerjaannya pegawai tidak semata-mata mengejar insentif sehingga mengabaikan mutu pekerjaan.

(Malayu .S.P. Hasibuan 2001) mengungkapkan jenis-jenis insentif tersebut sebagai berikut:

1. Piece work

Piece work adalah teknik yang berupa insentif finansial dan digunakan untuk mendorong kinerja kerja pegawai berdasarkan hasil kerja pekerjaan pegawai dinyatakan dalam jumlah unit produksi.

2. Bonus

Bonus adalah insentif yang diberikan kepada pegawai yang mampu sedemikian rupa sehingga tinggat produksi yang baku terlampaui.

3. Komisi

Komisi adalah bonus yang diterima karena berhasil melaksanakan tugas, dan sering diterapkan oleh tenaga-tenaga penjual.

4. Kurva "Kematangan"

Kurva "Kematangan" adalah insentif yang diberikan kepada tenaga kerja karena masa kerja dan golongan pangkat serta gaji tidak bisa mencapai pangkat dan penghasilan yang lebih tinggi lagi. Misalnya dalam bentuk penelitian ilmiah atau dalam bentuk beban mengajar yang lebih besar dan sebagainya.

5. Insentif Bagi Eksekutif

Insentif bagi eksekutif ini adalah insentif yang diberikan kepada pegawai khususnya manager atau pegawai yang memiliki kedudukan tinggi dalam suatu perusahaan, misalnya untuk membayar 
cicilan rumah, kendaraan bermotor atau biaya pendidikan anak.

6. Rencana Insentif Kelompok

Rencana insentif kelompok adalah kenyataan bahwa dalam banyak organisasi, kinerja bukan karena hasil individual melainkan karena keberhasilan kelompok kerja yang mampu bekeria sebagai suatu tim.

Pemberian insentif sangat efektif untuk mendorong kinerja para pegawai, karena selain menambah penghasilan mereka, pemberian insentif juga dapat menumbuhkan perasaan senang, bergairah dan bersemangat dalam dalam melakukan suatu pekerjaan.

Untuk memperjelas tujuan pemberian insentif diatas, terdapat beberapa pendapat menurut para ahli, diantaranya menurut (Malayu .S.P. Hasibuan 2013) mengemukakan pendapatnya mengenai insentif, bahwa: Metode Insentif yang adil dan layak merupakan daya penggerak yang merangsang terciptanya pemeliharaan pegawai.

\section{METODE PENELITIAN}

Objek Penelitian ini dilakukan di Badan Pengelola Pajak dan Retribusi Daerah Kota Bandar Lampung.

Dalam penelitian ini diperlukan data yang relevan dengan masalah penelitian. Ada dua jenis data yang dibutuhkan dalam penelitian ini, kedua data tersebut adalah :

1. Data Primer

Menurut (Juniadi dkk 2015) data primer adalah data yang berasal langsung dari sumber data yang dikumpulkan secara khusus dan berhubungan langsung dengan masalah penelitian yang akan diteliti. Sumber data primer pada penelitian ini didapat dari penyebaran angket yang berisi kuisioner.

2. Data Sekunder
Semua data yang tidak langsung diperoleh dari sumber pertama penelitian. Data ini erat kaitan dengan masalah yang diteliti seperti data-data yang sudah tersedia diperpustakaan berbentuk surat keputusan dan lain-lain (Arikunto, Suharsimi 2010).

Metode analisis statistik deskriptif menurut (Sugiyono 2011) merupakan statistik yang digunakan untuk menganalisis data dengan cara mendeskripsikan atau menggambarkan data yang telah terkumpul sebagaimana adanya tanpa maksud membuat kesimpulan yang berlaku untuk umum atau generalisasi dalam penelitian ini. Kriteria pengujian hipotesis:

1. Uji Partial (Uji t), Untuk menguji pengaruh variabel bebas terhadap variabel terikat secara parsial digunakan statistik uji t, dengan kriteria pengujian sebagai berikut : Dengan derajat kebebasan df: $\alpha$, (nk) dan taraf kepercayaan 95\% maka

2. Uji Simultan (Uji F), Untuk menguji pengaruh secara simultan variabel bebas (X1 dan X2) terhadap variabel terikat (Y) digunakan statistik Uji F dengan kriteria pengujian sebagai berikut : Dengan derajat kebebasan df. $\alpha$, (n-k) dan taraf kepercayaan 95\% maka terima hipotesis jika Fhitung $>$ Ftabel, dalam hal sebaliknya hipotesis ditolak.

Variabel bebas secara simultan mampu menjelaskan perubahan variabel terikat apabila probabilita pada nilai Fhitung $<$ dari probabilitas 0,05 .

\section{HASIL DAN PEMBAHASAN}

Hipotesis yang akan di uji adalah untuk mengetahui ada dan tidaknya pengaruh dari variabel independen (bebas) terhadap variabel dependen (terikat) secara parsial. 
Tabel coefficient menampilkan nilai koefisien regresi untuk menentukan persamaan regresi linier berganda.

Berdasarkan tabel Coefficient diperoleh persamaan regresi sebagai berikut

$$
Y=-11,541+0,471 X 1+0,180 X 2
$$

Dimana:

$\mathrm{Y}=$ Variabel terikat yaitu Kinerja

$\mathrm{X} 1=$ Variabel Motivasi

$\mathrm{X} 2=$ Variabel Insentif

Hasil Perhitungan Regresi Linier Berganda

\begin{tabular}{|c|c|c|c|c|c|c|}
\hline \multirow[t]{2}{*}{ Model } & & \multicolumn{2}{|c|}{$\begin{array}{l}\text { Unstandardized } \\
\text { Coefficients }\end{array}$} & \multirow[t]{2}{*}{$\begin{array}{l}\text { Standardized } \\
\text { Coefficients }\end{array}$} & \multirow[t]{2}{*}{$\mathrm{t}$} & \multirow{2}{*}{ Sig. } \\
\hline & & B & Std. Error & & & \\
\hline \multirow[t]{3}{*}{1} & (Constant) & 11.541 & 6.563 & & 1.758 & .083 \\
\hline & Motivasi & .471 & .138 & .369 & 3.423 & .001 \\
\hline & Insentif & .180 & .124 & .157 & 1.451 & .004 \\
\hline
\end{tabular}

a. Dependent Variable: Kinerja

Berdasarkan tabel di atas, dapat ditentukan bahwa :

1. $\mathrm{a}=11,541$ yang berarti bahwa tanpa adanya motivasi, insentif, maka besarnya kinerja pegawai adalah 11,541 satuan.

2. B1 (koefisien untuk motivasi) $=0,471$ yang berarti bahwa setiap kenaikan motivasi sebesar satu satuan, maka kinerja akan bertambah sebesar 0,471 satuan.

3. B2 (koefisien untuk insentif) $=0,220$ yang berarti bahwa setiap kenaikan insentif sebesar satu satuan, maka kinerja pegawai akan bertambah sebesar 0,180 satuan.

Pengujian hipotesis berganda :

Setelah memperoleh persamaan regresi berganda, selanjutnya akan dilakukan uji hipotesis dengan menggunakan Uji R, Uji F dan Uji t.

Berdasarkan tabel 22. menunjukkan bahwa variabel motivasi (X1), insentif (X2) secara bersama-sama memiliki hubungan yang signifikan terhadap variabel kinerja (Y), hal ini ditunjukkan oleh nilai korelasi $\mathrm{R}$ sebesar 0,403. Sedangkan berdasarkan koefisien determinan atau $\mathrm{R}$ square variabel motivasi (X1), insentif (X2) secara positif mampu menjelaskan variabel kinerja sebesar $16,30 \%$ sedangkan $83,70 \%$ dijelaskan oleh variabel lain selain variabel motivasi (X1), insentif (X2), hasil ini ditunjukkan besaran R square 0,163

Mengacu pada hasil output Anova dan berdasarkan tabel 23, menunjukkan bahwa hasil perhitungan uji statistik $F$ diperoleh nilai Fhitung sebesar 6,993 dan nilai Ftabel sebesar 3,133 dengan tingkat signifikan 0,05 derajat kebebasan v1(3-1) v2(75-2) dan taraf kepercayaan sebesar 95\%. Dengan demikian Fhitung $>$ Ftabel yaitu masing-masing sebesar 6,993 > 3,133. Secara statistik berarti Ho ditolak dan $\mathrm{Ha}$ diterima artinya sesuai kriteria pengujian maka hipotesis "Motivasi dan insentif berpengaruh secara, bersama-sama dan signifikan terhadap kinerja pegawai Badan Pengelola Pajak dan Retribusi Daerah Kota Bandar Lampung dapat dibuktikan.

Mengacu pada output coefficient, nilai t-hitung untuk motivasi sebesar $(3,423)$, nilai t-hitung insentif sebesar $(1,451)$ dengan t-tabel pada df 95\%, $\alpha$ 5\% dan n-2 sebesar 1,6682, maka:

a. Variabel X1 (Motivasi) mempengaruhi variabel (Y) kinerja karena memiliki nilai signifikansi sebesar 0,001 (lebih kecil dari 0,05).

b. Variabel X2 (Insentif) mempengaruhi variabel (Y) kinerja karena memiliki nilai signifikansi sebesar 0,004 (lebih kecil dari 0,05). 
Berdasarkan hasil pengujian hipotesis dapat disimpulkan bahwa secara parsial ada 2 variabel Motivasi dan Insentif mempunyai pengaruh secara signifikan terhadap kinerja pegawai Badan Pengelola Pajak dan Retribusi Daerah Kota Bandar Lampung secara simultan (bersama-sama).

Hasil penelitian ini menyatakan bahwa secara parsial Motivasi berpengaruh secara signifikan terhadap kinerja pegawai Badan Pengelola Pajak dan Retribusi Daerah Kota Bandar Lampung. Hasil penelitian ini mendukung penelitian yang menyimpulkan Motivasi berpengaruh terhadap kinerja pegawai. Hal ini sejalan dengan apa yang dikemukakan oleh Manahan (2010) bahwa dalam Ensiklopedia Administrasi Motivasi adalah dorongan mental terhadap perorangan atau orang-orang sebagai anggota kelompok dalam menggapai suatu peristiwa dalam masyarakat.

Hasil penelitian ini menunjukan bahwa secara parsial insentif berpengaruh secara signifikan terhadap kinerja pegawai Badan Pengelola Pajak dan Retribusi Daerah Kota Bandar Lampung. Kesignifikannya hasil penelitian ini di sebabkan karena dua faktor yaitu faktor intrinsik dan ekstrinsik. Untuk faktor intrinsik yaitu berkaitan dengan keteladanan pihak pimpinan khususnya kepala badan itu sendiri belum seluruhnya mampu untuk dijadikan sebagai panutan sehingga dalam melaksanakan pekerjaan belum sesuai dengan prosedur kerja standar organisasi.

Selain itu juga dipengaruhi oleh faktor-faktor manajemen rekrutmen dan seleksi penerimaan pegawai, pelatihan dan pengembangan, manajemen kompensasi, manajemen kinerja, manajemen karir, dan fungsi kontrol atasan dan sesama rekan kerja belum berfungsi sebagaimana yang di harapkan.

\section{KESIMPULAN DAN IMPLIKASI}

Penelitian ini bertujuan untuk mengetahui pengaruh motivasi dan insentif terhadap kinerja pegawai Badan Pengelola Pajak dan Retribusi Daerah Kota Bandar Lampung dari hasil penelitian dapat disimpulkan sebagai berikut :

1. Terdapat pengaruh motivasi terhadap kinerja pegawai Badan Pengelola Pajak dan Retribusi Daerah Kota Bandar Lampung dari hasil uji hipotesis secara parsial melalui uji $\mathrm{t}$ diperoleh nilai thitung sebesar 0,372 sedangkan $\mathrm{R}$ square 138 atau sebesar 13,80\% sedangkan sisanya dipengaruhi variabel lain yang tidak diteliti dalam penelitian ini.

2. Terdapat pengaruh insentif terhadap kinerja pegawai Badan Pengelola Pajak dan Retribusi Daerah Kota Bandar Lampung dari hasil uji hipotesis parsial melalui uji $\mathrm{t}$ diperoleh nilai thitung sebesar 0,163 sedangkan $\mathrm{R}$ square 0,26 atau sebesar $2,60 \%$ sedangkan sisanya dapat dipengaruhi oleh variabel lain yang tidak diteliti dalam penelitian ini.

3. Hasil pengujian hipotesis secara simultan motivasi dan insentif terhadap kinerja pegawai Badan Pengelola Pajak dan Retribusi Daerah Kota Bandar Lampung yang dibuktikan hasil perhitungan uji Fhitung sebesar 6,993 dan nilai Ftabel 3,133. Nilai R square 163 atau sebesar $16,30 \%$ sedangkan sisanya dipengaruhi variabel lain yang tidak diteliti dalam penelitian ini.

Adapun penjelasan tersebut diatas yang berkaitan dengan pengaruh motivasi dan insentif terhadap kinerja pegawai maka identifikasi masalah yang diperoleh adalah sebagai berikut :

1. Variabel motivasi, yang perlu mendapat perhatian yaitu nomor 5 adalah saya lebih senang bekerja mandiri dalam menyelesaikan pekerjaan yang ada, 
dengan demikian staf harus mampu meningkatkan kinerja dalam menyelesaikan tugas-tugas yang dibebankan kepadanya dengan penuh tanggungjawab.

2. Variabel insentif, yang perlu mendapat perhatian yaitu nomor 5 adalah insentif yang diberikan mencukupi kebutuhan, oleh sebab itu pekerjaan yang telah ia laksanakan harus dapat diselesaikan sesuai dengan jadwal yang telah ditetapkan dan tepat waktu.

3. Variabel kinerja, yang perlu mendapat perhatian yaitu nomor 7 adalah saya mampu membagi tugas sejumlah bidang, kerja saja dengan efektif, peningkatan indikator ini dapat dilakukan dengan baik dan berkonsentrasi pada jam kerja kantor dengan cara pimpinan selalu memberikan bimbingan dan pembinaan agar beban kerja dapat diselesaikan tepat waktu agar tujuan organisasi tercapai.

\section{DAFTAR PUSTAKA}

Aprianis. 2019. "PENGARUH

PELATIHAN DAN INSENTIF

TERHADAP KINERJA

OPERATOR SISTEM

KEUANGAN DESA

(SISKEUDES) DI KABUPATEN

PRINGSEWU.” Jurnal Ilmu

Manajemen Saburai (JIMS) 5(1):916.

Arikunto, Suharsimi. 2010. Prosedur Penelitian. Jakarta: Rineka Cipta.

Juniadi dkk. 2015. Metodologi Penelitian Bisnis Konsep Dan Aplikasi. Medan: UMSU Press.

Malayu .S.P. Hasibuan. 2001. Manajemen Dasar. Jakarta: Bumi Aksara.
Malayu .S.P. Hasibuan. 2013. Manajemen Sumber Daya Manusia. Jakarta: Bumi Aksara.

Pratama, Dhanang Bayu, and Bambang Swasto Sunuharyo. n.d. "PENGARUH INSENTIF DAN PROMOSI TERHADAP PRESTASI KERJA.” 6.

Robbin, S. P., \&. Judge. 2008. "Perilaku Organisasi." in Perilaku Organisasi.

Stevy Moniharapon. 2018. "Analisis Pengaruh Budaya Organisasi, Kompetensi Dan Beban Kerja Terhadap Kinerja Aparatur Sipil Negara (ASN) Pada Kopertis Wilayah XII Di Kota Ambon.” Jurnal Manis. Universitas

Pattimura, Ambon. 2(2).

Sugiyono. 2011. "Metode Penelitian Kombinasi." Bandung: Alfabeta.

Suranto. 2013. "Pengaruh Motivasi Kerja, Kepuasan Kerja. Budaya.” Jakarta: Gramedia. 